\title{
Invasive forms of canine endoparasites as a potential threat to public health - A review and own studies
}

\author{
Mariusz Zbigniew Felsmann', Mirosław Mariusz Michalski², Mirosława Felsmann³, \\ Rajmund Sokół², Józef Szarek4, Emilia Strzyżewska-Worotyńska ${ }^{4}$ \\ ${ }^{1}$ Faculty of Veterinary Medicine and Animal Science, Institute of Veterinary Medicine, Poznań University of Life Sciences, \\ Poznań, Poland \\ ${ }^{2}$ Department of Parasitology and Invasive Diseases, Faculty of Veterinary Medicine, University of Warmia and Mazury, \\ Olsztyn, Poland \\ ${ }^{3}$ Faculty of Health Science, Collegium Medicum in Bydgoszcz, Nicolaus Copernicus University in Toruń, Bydgoszcz, Poland \\ ${ }^{4}$ Department of Pathophysiology, Forensic Veterinary Medicine and Administration, Faculty of Veterinary Medicine, \\ University of Warmia and Mazury, Olsztyn, Poland
}

Felsmann MZ, Michalski MM, Felsmann M, Sokół R, Szarek J, Strzyżewska-Worotyńska E. Invasive forms of canine endoparasites as a potential threat to public health - A review and own studies. Ann Agric Environ Med. 2017; 24(2): 245-249. doi: 10.5604/12321966.1235019

\begin{abstract}
Dogs serve as the vectors of serious zoonotic parasitic diseases. In the month of May 2012 - 2014, 339 dog faeces samples from seven public sites in Chełmno, a town in northern Poland, were collected and examined to determine the gastrointestinal parasite fauna of dogs. Each faecal sample was dissected with a needle, checked for tapeworm segments and examined for parasite eggs and oocysts using the flotation and decantation method and a modified Baermann technique. Differences were observed in the degree of parasite species occurrence. The most dominant were Toxocara canis and Ancylostomatidae. The detected species included: T. canis and Toxascaris leonina eggs ( $23.4 \%$ and $10.2 \%$, respectively), as well as eggs from the Ancylostomatidae family (16.2\%), Trichuris vulpis eggs (6.6\%), Taenia type eggs (4.6\%), Dipylidium caninum (5.2\%) and Cystoisospora (Isospora) spp. oocysts (10.9\%).
\end{abstract}

- Key words

parasitic zoonosis, public health, urban and public places, endoparasites, dogs, geohelminths.

\section{INTRODUCTION}

Dogs are infected with many parasite species $[1,2,3,4]$. The most infected are stray dogs [5]. However, the awareness of owners about the potential environmental contamination their pets can cause with invasive forms of parasites that may lead to severe diseases in humans is insufficient, similar to the awareness of the need for developing hygienic habits [2, $4,6,7,8]$. The development of modern human settlements reduces green zone areas. Dog owners are forced to walk their pets in small areas that are frequently visited by humans, such as parks or beaches $[4,7,9,10]$. This leads to permanent contamination of the public space with invasive forms of parasites that colonize the canine gastrointestinal tract and lead to the persistence of this contamination $[3,4,9,10,11$, $12,13]$. Eggs and larvae of geohelminths are a severe threat to children $[9,12,14]$. This threat is the greatest in parks and in playgrounds $[4,10,12,14,15,16]$.

Local authorities are mainly interested in removing canine faeces from roads, pavements and hardened park pathways purely for aesthetic reasons. Removal of canine faeces from lawns and green areas is still uncommon among dog owners. The life cycle of many intestinal parasites, especially those of the Ascaris genus, require that the roundworm eggs get into soil $[10,12,14,15,16]$. This characteristic of

Address for correspondence: Mariusz Felsmann, Poznań University of Life Sciences, Faculty of Veterinary Medicine and Animal Science, Institute of Veterinary Medicine, Wołyńska 35, 60-637 Poznań, Poland

E-mail: felsmann.mariusz@wp.pl

Received: 3 March 2016; accepted: 22 April 2016; first published on February 2017 some geohelminths makes them dangerous to humans in this developmental stage [17]. This threat is increased by organisms found in the upper layer of soil (for instance earthworms) and on its surface (for example, snails) that spread these invasive forms of parasites over extensive distances [18]. Considering the number of geohelminth eggs that may be present in canine faeces and the survival of eggs in soil, it should be emphasized that they present a problem even if single animals are the source of contamination [15, 17, 19]. For instance, Toxocara spp. eggs, due to their high resistance to various physical, chemical and biological factors (they may survive in soil in an invasive form for several years), have become a specific bio-indicator of environmental contamination with canine and feline faeces [20].

Children are most at risk of accidental ingestion of invasive parasitic forms $[12,14,15,21,22]$. These threats occur as a result of child mobility, especially in parks and in playgrounds where children often touch the ground with their hands, which, when lacking hygienic habits, may facilitate the transmission of contamination from the hand to the mouth $[15,16,17,21]$. In this context, a negative role is played by habits acquired in early childhood, namely geophagia (soil eating) and onychophagia (compulsive nail biting) [15, 17, 21]. Considering these facts, it should be emphasized that threats to public health are closely associated with the status of the environment in which people live $[1,23]$. 


\section{OBJECTIVE}

To monitor the occurrence of the invasive stages of endoparasites in selected urban areas of Chełmno.

\section{MATERIALS AND METHOD}

Study design. The research was conducted in Chełmno, a town situated on the Vistula River in northern Poland, covering an area of $13.86 \mathrm{~km}^{2}$ with approximately 19,000 residents. 825 dogs were registered in the town in 2013 by 795 owners. Samples for analyses were collected at seven different sites in accessible public areas. Site S1 (Stare Planty) is a park located in the north-western part of the old town. This site is most commonly visited by dog owners who live in the old town and for whom this is the only directly accessible green square. Stare Planty is not a popular location for walking and playing. Site S2 (Nowe Planty) is a part of the old moat located in the north-eastern part of Chełmno. This park is often visited by residents of the town, including those with small children because of the playground situated there. Site $\mathrm{S} 3$ is located on the top of a slope in the southern part of the town. This area is covered with sandy soil that is exposed to the direct impact of sunlight. Because of its location, this area is used by residents as a communication pathway rather than a recreation spot. Site $\mathrm{S} 4$ is a cascade of lawn and green areas situated between multi-family buildings on a housing estate located at the foot of a slope in the south-western part of the town. Due to the location of the housing estate, dog owners do not walk their dogs outside this area. Site S5 is composed of green squares along a block of flats situated in a cascade on a slope in the north part of the town. The residents of this housing estate do not have direct access to other green areas. Site S6 includes green squares and lawns around new blocks of flats situated in the eastern part of the town. This was the only place where it was difficult to find samples for analyses, which may indicate that dog owners often remove canine faeces. Site S7 is a large lawn and an alley near a preschool. This area is situated on the top of a slope in the south-eastern part of the town on the outskirts of a housing estate dating from the late 1960s. This area is a playground (including a fenced preschool playground) with a sandbox which is oftenvisited by dog owners who do not clean up after their pets.

Faecal samples. The study was conducted in $2012-2014$ by collecting canine faeces in May between 08:00-09:00. Each year, 113 samples were taken from seven selected public sites in Chełmno (Sites 1-7) most frequently visited by dog owners (Tab. 1). A total of 339 faecal samples were collected from lawns and green areas near alleys and pathways in the parks.

Parasitological procedures. The faecal samples were stored in plastic tubes at $4^{\circ} \mathrm{C}$ for a week before the analyses were started. Each sample was examined individually for the presence of coccidial oocysts, nematode eggs, tapeworm eggs and proglottids. All samples were examined with a standardized flotation method, with a saturated solution of salt with magnesium sulphate and sodium chloride (specific gravity: 1.280 and 1.200 ). The material was additionally examined with the sedimentation method according to a modified Baermann's technique. Identification of oocysts and parasite eggs was performed based on their morphological characteristics [24].

\section{RESULTS}

The results of the research (including all groups of parasites and sites of sampling) are presented in the summary Table (Tab. 1).

The developmental stages of all groups of parasites were not simultaneously detected at any of the sites. In three subsequent years of the study, the presence of the dispersal forms of five parasitic groups was confirmed only at two sites (S2 and S7), whereas at two other sites (S4 and S5) the dispersal forms of four parasitic groups were reported. The presence of developmental stages of three groups of parasites was detected at two sites (S1 and S6) and only parasites from one group were found in the samples from one site (S3). The degree of contamination of the faecal samples with invasive forms of the individual groups of parasites was differential for the individual collection sites (Tab. 1). These included the following: Cystoisospora (Isospora) spp. oocysts, tapeworm eggs, Dipylidium caninum (eggs or proglottids), Toxocara canis

Table 1. Results of microscopic examination of canine faeces collected from public places in Chełmno, 2012-2014 (\%)

\begin{tabular}{|c|c|c|c|c|c|c|c|c|c|c|c|c|c|c|c|c|c|c|c|c|c|}
\hline \multirow{3}{*}{ Site } & \multicolumn{21}{|c|}{ Identified species of parasites (\%) } \\
\hline & \multicolumn{3}{|c|}{ Cystoisospora spp. } & \multicolumn{3}{|c|}{ Taeniidae } & \multicolumn{3}{|c|}{$\begin{array}{l}\text { Dipylidium- } \\
\text { caninum }\end{array}$} & \multicolumn{3}{|c|}{ Toxocaracanis } & \multicolumn{3}{|c|}{ Toxascarisleonina } & \multicolumn{3}{|c|}{$\begin{array}{l}\text { Ancylostoma- } \\
\text { tidae }\end{array}$} & \multicolumn{3}{|c|}{ Trichurisvulpis } \\
\hline & 12 & 13 & 14 & 12 & 13 & 14 & 12 & 13 & 14 & 12 & 13 & 14 & 12 & 13 & 14 & 12 & 13 & 14 & 12 & 13 & 14 \\
\hline S1 $(n=46)$ & 10.5 & 5.3 & 25.0 & - & - & - & 5.3 & 5.3 & - & - & - & - & - & - & - & 10.5 & 10.5 & 12.5 & - & - & - \\
\hline $\mathrm{S} 2(\mathrm{n}=58)$ & 12.0 & 8.0 & 12.5 & 4.0 & 4.0 & - & - & - & - & 16.0 & 12.0 & 37.5 & - & - & - & 12.0 & 12.0 & 25.0 & 8.0 & 4.0 & - \\
\hline$S 3(n=50)$ & - & - & - & - & - & - & - & - & - & 21.0 & 20.8 & 42.8 & - & - & - & - & - & - & - & - & - \\
\hline S4 $(n=52)$ & - & 9.1 & 12.5 & - & - & - & - & - & - & 4.5 & 13.6 & 25.0 & 9.1 & 9.1 & 12.5 & 27.3 & 18.2 & - & - & - & - \\
\hline S5 $(n=56)$ & 8.3 & 4.2 & - & - & - & - & 4.2 & - & - & 20.8 & 25.0 & 37.5 & - & - & - & 8.3 & 8.3 & - & - & - & - \\
\hline$S 6(n=38)$ & - & - & - & 6.7 & - & - & - & - & - & - & - & - & - & - & - & 26.7 & 20.0 & 12.5 & 6.7 & 6.7 & - \\
\hline S7 $(n=39)$ & 9.1 & 3.2 & - & - & - & - & 9.1 & 3.2 & - & 27.3 & 9.7 & 37.5 & - & - & - & 18.2 & 6.4 & 25.0 & 9.1 & - & - \\
\hline Total prevalence & 10.0 & 6.0 & 16.7 & 5.3 & 4.0 & - & 6.2 & 4.2 & - & 18.0 & 16.2 & 36.1 & 9.1 & 9.1 & 12.5 & 17.2 & 12.6 & 18.7 & 8.0 & 5.3 & \\
\hline Total prevalence 2012-2014 & & 10.9 & & & 4.6 & & & 5.2 & & & 23.4 & & & 10.2 & & & 16.2 & & & 6.6 & \\
\hline
\end{tabular}

$\mathrm{n}=$ number of examined samples; - = not found; $\%=$ prevalence (positive $\%) ; 12,13,14=$ successive years of research $(2012,2013,2014)$ 


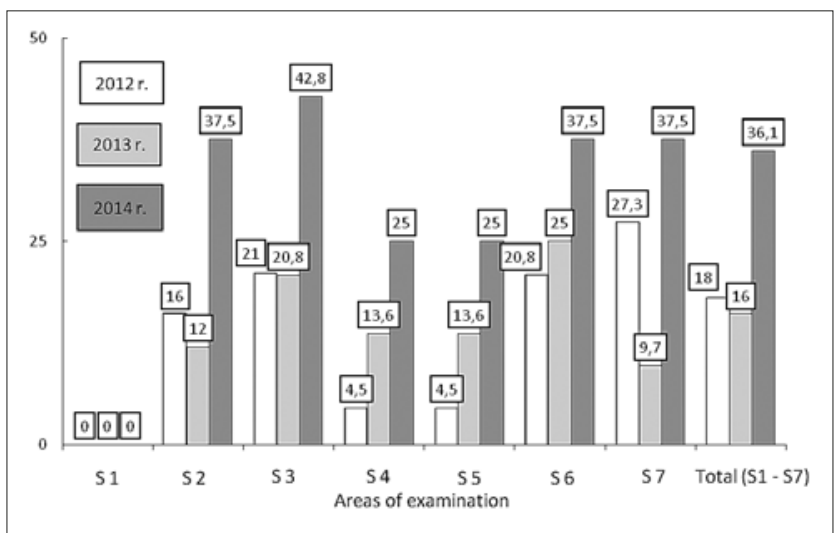

Figure 1. Prevalence of T. canis in canine faecal samples collected at 7 sites within urban public spaces, 2012-2014

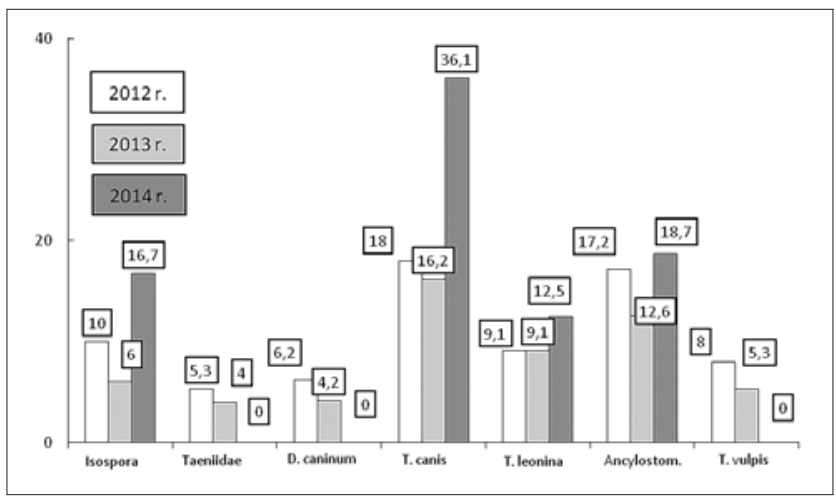

Figure 2. Average proportion of individual invasive forms of parasites in faecal samples, 2012-2014

and Toxascaris leonina eggs, Ancylostomatidae (Ancylostoma spp. and/or Uncinaria spp.) and Trichuris vulpis eggs.

During the study period, there was an increase in the level of canine roundworm eggs (Toxocara canis) contamination by nearly $100 \%$. In 2014, eggs of this parasite were detected, on average, in $36.1 \%$ of the samples, and at site S3 this contamination was confirmed in $43 \%$ of the samples. Cystoisospora (Isospora) spp. oocysts were detected at five sites, out of which two sites displayed the presence of this parasite during all three study years, and the other three sites in two subsequent years. The prevalence of contamination of the samples ranged from $6.0-16.7 \%$ with the highest result recorded at S1 (13.6\%) and the lowest at S7 (6.15\%). Tapeworm eggs from the Taeniidae family were detected at two sites (S2 and S6): in the first case, in two subsequent experimental years and in the second case only in the first year. The prevalence of contamination of the samples in 2012 - 2014 ranged from $4.0-5.3 \%$. Eggs or proglottids of D. caninum were found at three sites (S1, S5 and S7), including two cases in two years of the study and one case only in the first year of the study. The prevalence of contamination of the samples in 2012-2013 ranged from $4.2 \%-6.2 \%$. T. canis eggs were present at five sites in three subsequent years of the study. The highest prevalence of contamination of the samples was detected on S3 (28.2\%) whereas the lowest was at S4 (14.4\%). In two subsequent years, infestation with T. canis dropped from $18.0 \%$ to $16.2 \%$ and then reached $36.1 \%$ in 2014 . T. leonina eggs were detected in only one public site (S4) in all the years of the study, and the prevalence of contamination of the samples was $9.1 \%$ in 2012 and 2013 and $12.5 \%$ in 2014. Hookworm eggs from the
Ancylostomatidae family were found at six sites in the town, including four cases in three subsequent years of the study, and in two cases in two subsequent years of the study. The prevalence of contamination of the samples ranged from $12.6 \%-18.7 \%$. Whipworm eggs (T. vulpis) were found at three sites, including two locations in two subsequent years of the study and at one site (S7) only in 2012. The prevalence of contamination of the samples in 2012-2013 ranged from $5.3-8.0 \%$.

\section{DISCUSSION}

The diversity in contamination of canine faeces with dispersal forms of different groups of parasites in the individual years and sites indicates the potential for contamination of all public spaces at virtually any time. Therefore, it is assumed that threats posed by invasive forms of parasites found in canine faeces present a constant and non-diminishing hazard to public health. The samples of canine faeces were contaminated mainly with nematode eggs (14.1\%) and with Cystoisospora (Isospora) spp. oocysts (10.9\%). The present epidemiological study revealed that $T$. canis is the most common parasite in the urban areas of Chełmno (23.4\%). This is a particularly high risk to public health given that there was an incremental presence of invasive forms of T. canis during the study period in all areas where the samples were collected. At all sites where eggs of this parasite were detected, the prevalence of contamination of the faecal samples was highest in the last year of the study, which may suggest a progressive increase of the resistance to administered drugs or infrequent de-worming of dogs during the year. This phenomenon increased along with incremental contamination of public spaces with eggs of this nematode.

In Poland, the degree of biological contamination of soil with $T$. canis eggs in urban areas was divers, ranging from $6 \%$ in Wrocław to 30\% in Kraków and 36\% in Lublin [20, 25, 26, 27, 28]. Tylkowska [29], while investigating faecal samples of dogs from Western Pomerania, found eggs of five nematode species: T. canis (20.62\%), Toxascaris leonina (2.91\%), Uncinaria stenocephala (11\%), Ancylostoma sp. (4.61\%), and Trichuris vulpis (0.27\%). In Western Europe, the level of contamination of the urban environment with eggs of these parasites ranges from $3.5 \%-17 \%[7,30]$, while in Central Europe, contamination of urban spaces with T. canis oscillated within the $21.9 \%-30.1 \%$ range $[31,32]$. In the south of Spain, this level was only $17.72 \%$ [33].

In own reaserch, Toxascaris leonina eggs were found in $10.2 \%$ of faecal samples. In other Polish cities, this percentage ranged from $2.91 \%$ in Western Pomerania to $8.8 \%$ in Lublin, eastern Poland $[28,29]$. In Germany, the level of contamination was only 0.6\% [30]. In Central Europe, it ranged between $2.1 \%-7.3 \%[31,32]$, whereas in the south of Spain it reached nearly $15 \%$ [33].

Ancylostomatidae (Ancylostoma spp. and/or Uncinaria spp.) eggs were found in $16.2 \%$ of the faecal samples collected in Chelmno. In Poland, the prevalence of eggs of this nematode in cities vary from occasional cases (Gdańsk) to over 13\% (Szczecin) [26, 29]. According to other authors, hookworms (Ancylostoma sp. and Uncinaria sp.) are the most commonly-found helminths in dogs. In Western Europe, the prevalence of hookworms ranges from $2.2 \%$ in Germany to $11.4 \%$ in Belgium $[22,30]$. In Finland, infection with 
U. stenocephala was only reported in $2.6 \%$ of dogs [34]. A higher percentage (8.1\%-18.4\%) has been observed in Central Europe [31, 32]. The highest level $(33.27 \%)$ was reported in the south of Spain [33].

Trichuris vulpis eggs were detected in $6.6 \%$ of the faecal samples in the current study. A gradual decrease in the prevalence of faecal contamination with whipworm eggs and the lack thereof in the third year of the study may indicate the progressive effectiveness of diagnostics and treatment of this infestation. Other researchers reported a much lower level of contamination of public spaces in Poland with eggs of this nematode $-0.27 \%-3.8 \%[28,29]$. A comparably low proportion of contamination has been reported in Finland and Germany $[30,34]$. In contrast, contamination with invasive forms of this parasite in Europe ranged from 10.0\% to over $23 \%[31,32]$.

Tapeworm eggs of species belonging to the Taeniidae family (these eggs are virtually identical to those of Echinococcus species) were found in $4.6 \%$ of the faecal samples collected for research by the authors of the presented study. In other Polish cities, eggs or proglottids of Taenia spp. were found in canine faeces at the level of $0.46-3.45 \%[29,35]$. Similar results have been reported in Germany, Slovakia and Hungary [30, 31, 32].

Eggs or proglottids of Dipylidium caninum were found in $5.2 \%$ of the faecal samples, with a downward tendency and negative result in the third year of the study. This could have resulted from a gradual elimination of flea infestation. Similar results have been reported in studies conducted in different cities in Poland $[26,27,29]$. A slightly higher proportion (10.0\%) was detected in the Lublin Province (eastern Poland) [35]. A significantly lower level of contamination was recorded in Hungary (up to 1\%) [31].

Cystoisosporosis is a protozoal canine and feline disease. An etiological factor of this disease are coccidian Cystoisospora (Isospora) spp. These oocysts were detected in $10.9 \%$ of the tested faecal samples with a clear increase in the prevalence of positive samples in the last year of the study. This may suggest a misdiagnosis of the infestation, especially in young dogs, and thus ineffective treatment of animals. Similar findings have been reported in Slovakia [32]. In Western Europe and Hungary, results were lower by half $[30,31,36]$.

Zoonoses involving dog parasites are both common and important, with some causing serious disease. Above all, Toxocara spp. (T. canis) is capable of infecting and inducing disease (larva migrans syndromes) in human beings who accidentally ingest the infective stages (eggs or larvae, respectively). Studies conducted worldwide have demonstrated frequent contamination of yards, sandboxes, parks, playgrounds, beaches and other public spaces with Toxocara eggs $[10,30,37]$. Due to the fact that it is not possible to reduce the number of eggs in the environment, it becomes very important to prevent contamination of the environment, which may be achieved by eliminating patent infestation with parasites, preventing defecation of animals in public places and removing faeces [7]. Contamination of the environment, with developing stages of helminths, potentially able to threaten human health, is an important problem from the aspect of hygiene and the public health service. Parks and other public areas contaminated with dog faeces are important areas for the transmission of parasitic diseases from the environment to humans [32]. The presence of intestinal parasites found in the current study confirmed the high risk of human infection with zoonotic diseases.

\section{CONCLUSIONS}

It is difficult, or even impossible, to precisely determine the cause of qualitative and quantitative variation in contamination of faeces collected at the individual sites. This study depicts and proves that even in a small town with dense buildings the threats to public health are various. This threat is potentiated by the unawareness of residents of the potential danger presented by invasive forms of parasites that are found in soil in public spaces. It is worth emphasizing that some areas that are heavily contaminated with eggs of nematodes, which are very dangerous to children, are used as playgrounds.

The present study also demonstrates that contamination of public spaces varies in time. This fact, together with the potential of geohelminths for surviving in soil for many years, makes these areas very dangerous, even if contamination with invasive forms is only occasional. The unawareness of local authorities and rare testing in small towns excludes (in the domain of public health) concern for disrupting the pathways of transmission of parasitic diseases that are simultaneously zoonoses. The presented results indicate that playing areas for children should be continuously covered with special protection against penetration by animals, including pets. Moreover, parents and child minders should be aware of threats to children sharing places used by animals, especially when children, while playing, have contact with soil or are exposed to inhalation of dust from the ground.

\section{REFERENCES}

1. Habluetzel A, Traldi G, Ruggieri S, Attili AR, Scuppa P, Marchetti R, Menghini G, Esposito F. An estimation of Toxocara canis prevalence in dogs, environmental egg contamination and risk of human infection in the Marche region of Italy. Vet Parasitol. 2003; 113: 243-252.

2. Katagiri S, Oliveira-Sequeira TCG. Prevalence of dog intestinal parasites and risk perception of zoonotic infection by dog owners in São Paulo State, Brazil. Zoonoses Public Health. 2008; 55: 406-413.

3. Deplazes, P, van Knapen F, Schweiger A, Overgaauw PAM. Role of pet dogs and cats in the transmission of helminthic zoonoses in Europe, with a focus on echinococcosis and toxocarosis. Vet Parasitol. 2011; 182: 41-53.

4. Sprenger LK, Green KT, Molento MB. Geohelminth contamination of public areas and epidemiological risk factors in Curitiba, Brazil. Braz J Vet Parasitol. 2014; 23: 69-73.

5. Zibaei M, Sadjjadi SM, Sarkari B. Prevalence of Toxocara cati and other intestinal helminths in stray cats in Shiraz, Iran. Trop Biomed. 2007; 24: 39-43.

6. Stańczyk A, Wlazłowski J, Kardas-Sobantka D, Chlebna-Sokół D. Toxocara seropositivity in children with atopic diseases. Alergia Astma Immunologia. 1999; 4: 251-254.

7. Overgaauw PAM, van Knapen F. Toksokaroza - ważna zoonoza. Mag Wet. 2009; 18: 1050-1058.

8. Ojha SC, Jaide C, Jinawath N, Rotjanapan P, Baral P. Geohelminths: public health significance. J Inf Dev Countr. 2014; 8: 005-016.

9. Paul M, Stefaniak J, Twardosz-Pawlik H, Pecold K. The co-occurrence of Toxocara ocular and visceral larva migrans syndrome: a case series. Cases J. 2009; 2: 6881

10. Iannacone J, Alvariño L, Cárdenas-Callirgos J. Contamination of soil with eggs of Toxocara canis in public parks of Santiago de Surco, Lima, Peru, 2007-2008. Neotrop Helminthol. 2012; 6: 97-108.

11. Wiśniewska-Ligier M, Woźniakowska-Gęsicka T, SobolewskaDryjańska J, Markiewicz-Jóźwiak A, Wieczorek M. Analysis of the course and treatment of toxocariasis in children - a long-term observation. Parasitol Res. 2012; 110: 2363-2371.

12. Núñez CR, Martínez GDM, Arteaga SY, Macotela MP, Montes PB, Durán NR. Prevalence and risk factors associated with Toxocara canis infection in children. Scien World J. 2013; Article ID 572089, 4 pag. 
13. Strunz EC, Addiss DG, Stocks ME, Ogden S, Utzinger J, Freeman MC. Water, sanitation, hygiene, and soil-transmitted helminth infection: a systematic review and meta-analysis. PLOS Medicine. 2014; 11: e1001620.

14. Kondera-Anasz Z, Kubala A, Mielczarek-Palacz A. Toxocariasis - a current clinical and diagnostic problem. Wiad Lek. 2005; 58: 218-221.

15. Finsterer J, Auer H. Neurotoxocarosis. Rev Inst Med Trop S Paulo. 2007; 49: 279-287.

16. Overgaauw PAM, van Knapen F. Veterinary and public health aspects of Toxocara spp. Vet Parasitol. 2013; 193: 398-403.

17. Dzbeński TH. Toksokaroza ośrodkowego układu nerwowego. Pol Przeg Neurolog. 2007; 3: 29-32.

18. Mizgajska H. Eggs of Toxocara spp. in the environmental and their public health implications. J Helminthol. 2001; 75: 147-151.

19. Felsmann M, Felsmann MZ. Toxoplasmosis and toxocarosis - the practical aspects of the difficulties in the breaking of the routes of diseases' spreading. In: Banaszkiewicz M, Kiełbratowska B, Gierszewska $M$ (ed.) The chosen aspects of woman and family's health. 1 st. ed. Bydgoszcz, Vol. II:125-133, 2010.

20. Mizgajska H. Zanieczyszczenie gleby jajami Toxocara spp. na terenie Krakowa i pobliskich wsi. Wiad Parazytol. 2000; 46: 105-110.

21. Dobosz S, Marczyńska M, Polielska J, Żarnowska-Prymek H. Reasons for searching for Toxocara infection and clinical manifestations of paediatric toxocarosis in Poland. Ped Wsp Gastroenter Hep Ż D. 2007; 9: 247-250.

22. Dubna S, Langrova I, Napravnik J, Jankowska I, Vadlejch J, Pekar S, Fechtner J. The prevalence of intestinal parasites in dogs from Prague, rural areas and shelters of the Czech Republic. Vet Parasitol. 2007; 145: $120-128$

23. Soriano SV, Pierangeli NB, Roccia I, Bergagna HFJ, Lazzarini LE, Celescinco A, Saiz MS, Kossman A, Contreras PA, Arias C, Basualdo JA A wide diversity of zoonotic intestinal parasites infects urban and rural dogs in Neuque'n, Patagonia, Argentina. Vet Parasitol. 2010; 167: 81-85.

24. Cencek T, Ziomko I, Karamon J, Sroka J, Zdybel J. Zarys weterynaryjnej diagnostyki parazytologicznej. 1st ed. Puławy, PIW, 2009.

25. Jarosz W. Zanieczyszczenie gleby jajami Toxocara spp. na terenie Elbląga. Wiad Parazytol. 2001; 47: 143-149.
26. Rokicki J, Kucharska AP, Dzido J, Karczewska D. Contamination of playgrounds in Gdańsk city with parasite eggs. Wiad Parazytol. 2007; 53: $227-230$

27. Balicka-Ramisz A, Ramisz A, Pilarczyk B, Jabłonka A. Skażenie środowiska jajami endopasożytów przewodu pokarmowego psów w wybranych miejscach Stargardu Szczecińskiego. In: Proceedings of XXII Zjazdu PTP, 1-3. 09. 2010; Puławy: 96, 2010 (in Polish).

28. Rzymowska J, Bartosik M, Kolasa S. Zanieczyszczenie terenu miasta Lublina jajami geohelmintów. In: Proceedings of XXII Zjazdu PTP, 1-3. 09. 2010; Puławy: 92, 2010 (in Polish).

29. Tylkowska A, Pilarczyk B, Gregorczyk A, Templin E. Gastrointestinal helminths of dogs in Western Pomerania. Wiad Parazytol. 2010; 56: 269-276.

30. Horn K, Schnieder T, Stoye M. Contamination of public children's playgrounds in Hannover with helminth eggs. Dtsch Tierarztl Wschr. 1990; 97: 122 .

31. Szatrami FE, Busak V, Rozgonyi F. Prevalence of intestinal parasites in dogs in some urban and rural areas of Hungary. Vet Quarterly. 2001; 23: 96-98.

32. Szabova E, Juris P, Miterpakova M, Antolova D, Papajova I, Sefcikova H. Prevalence of important zoonotic parasites in dog populations from the Slovak Republic. Helminthologia. 2007; 44: 170-176.

33. Martinez-Moreno FJ, Hernandez S, Lopez-Cobos E, Becerra C, Acosta I, Martinez-Moreno A. Estimation of canine intestinal parasites in Cordoba (Spain) and their risk to public health. Vet Parasitol. 2007; 143: 7-16.

34. Pullola T, Vierimaa J, Saari S, Virtala AM, Nikander S, Sukura A. Canine intestinal helminthes in Finland: prevalence, risk factors and endoparasite control practices. Vet Parasitol. 2006; 140: 321-326.

35. Samojłowicz M. Inwazje tasiemców u zwierząt mięsożernych na Lubelszczyźnie i trudności w ich rozpoznawaniu. Życie Wet. 2006; 81: 404-406.

36. Sager H, Moret CS, Mueller N, Staubli D, Esposito M, Schares G, Haessig M, Staerk K, Gottstein B. Incidence of Neospora caninum and other intestinal protozoan parasites in populations of Swiss dogs. Vet Parasitol. 2006; 139: 84-92.

37. Barutzki D, Schaper R. Results of parasitological examinations of faecal samples from cats and dogs in Germany between 2003 and 2010. Parasitol Res. 2010; 109: 45-60. 